\title{
Use of Best Management Practices (BMP) by the Farmers
}

\author{
Muhammad Humayun Kabir ${ }^{1}$, Sk. Md. Nur-E-Alam², Md. Omar Faruq ${ }^{3}$ and Md. Saiful Islam*, \\ 1,2,3 and 4 Department of Agricultural Extension and Information System, Sher-e-Bangla Agricultural University \\ Dhaka, Bangladesh. \\ *Corresponding author's email: mdsaiful.sumon52 [AT] gmail.com
}

\begin{abstract}
The purposes of the study were to describe selected characteristics of the use of best management practices farmers; to determine the extent of use of best management practices and to find out the factor that significantly influences use of best management practices. The study was conducted with randomly selected 84 farmers in Dhamrai upazila under Dhaka district. The use of best management practices by the farmers was the independent variable. Seventeen selected characteristics of the farmers considered as independent variables of the study. The data revealed that the majority (60.7\%) of the farmers had medium level of use of best management practices while $22.6 \%$ and $16.7 \%$ of them had low and high use of best management practices respectively. Out of selected seventeen characteristics, five namely education, use of mobile phone, time spent in farming, contact with SAAO and ownership of mobile phone had significant positive contribution to their use of best management practices by the farmers. Therefore, it can be recommended that initiative should be taken by the DAE with the help of other relevant organizations to increase these facilities (significant factors) to improve the scenario regarding use of best management practices.
\end{abstract}

Keywords--- Best Management Practices, Bangladesh agriculture, Regression analysis

\section{INTRODUCTION}

Bangladesh is a country of high population. The current population of the country is $163,046,161$, a $1.03 \%$ increase from 2018 [1]. As the population of the country is ever increasing, the farm holding size of a family is ever decreasing. So the demand of best management practices increases day by day to solve the land use problem. Nowadays all cultivable land is in use and the pressure of increasing population reduced the average size of the farm holding from 1.69 acres in 1996 to 1.48 acres [2]. At present we are in need of food for vast population. Production status of agricultural and livestock crop and others production related to nutrition are not sufficient according to our demand. It urgently needed to increase production of crops. Best Management Practices (BMP) practices can be served as an important issue to increase production of crops.

Best Management Practices (BMP) is a common sense approach to farming. It combines the best of traditional methods with appropriate modern technology, balancing the economic production of crops with positive environmental management [3]. It is based on understanding the intricate balance between our environment and agriculture and is a whole-farm approach in achieving a proper balance. Basic components of BMP are crop management, nutrient management, pest management, and financial management. Each of these components of BMP is associated with agricultural Integrated Crop Management Practices (ICM). Each ICM overlaps between the broader components of BMP. The relationship between farm management and BMP implementation is very dynamic. For instance, crop rotations can be used for reduced erosion and nutrient mobility, increased pest prevention, and better nutrient balancing through the use of nitrogen fixing plants [4]. Through the process of BMP, farmers make better use of on-farm resources. In the end, BMP and subsequent improved use of on-farm resources cause a reduced dependency on outside inputs of fertilizers, pesticides, and herbicides through the integration of farm management components and best management practices.

BMP is an approach to farming which aims to balance production with economic and environmental considerations by means of a combination of measures including crop rotation, cultivations, appropriate crop varieties and careful use of inputs. Best Management Practices can be thought of as a concept defining ideals and goals which then have to be 'translated' into definitions that can be implemented by farmers. Simply put, the concept is to integrate the management of individual crops in order to benefit from the interactions between them. In many respects integrating crop production strategies to provide benefits such as pest control, maintain soil fertility, etc. is an ancient technique [5]. However, BMP also takes advantage of modern technology to improve on the system. 
Most of the farmers are not aware about recommended dose of fertilizers and pesticides. Moreover they want to ignore to use some environmental friendly practices. But these overdosed pesticides and fertilizers are toxic in nature and hazardous to environment and human health. In this context BMP is safe in nature and eco-friendly. On the basis of the findings of the present study specific recommendation would be made for realistic policy formulation which would help the farmers to become aware about using BMP practices instead of traditional practice.

In Bangladesh, biological control and pheromone traps are used to manage some pests. Organic manures are used instead of chemical fertilizers. Mechanized cultivation system is used to reduce traditional methods. Savar upazila under Dhaka district is an important place of various crop (cereal, pulse, vegetables and fruit) cultivation in this country. BMP production techniques can be implemented instead or with conventional farming to increase production of crops and also for safe food. To expand this technique, the knowledge on the present situation of BMP in this region would be contributory to design appropriate programs for its widespread necessity. Therefore, it is necessary to conduct a study on Use of best management (BMP) practices by the farmers of Dhaka district.

- To describe the selected characteristics of the farmers.

- To determine the extent of use of best management practices by the farmers.

- To explore the contributions of the selected individual characteristics of the farmers on their use of best management practices.

\subsection{Study Location and Sampling}

\section{METHODOLOGY}

The study was conducted at Dhamrai upazila under Dhaka district. Dhamrai upazila area of $303.36 \mathrm{sq} \mathrm{km}$, located in between $23^{\circ} 49^{\prime}$ and $24^{\circ} 03^{\prime}$ north latitudes and in between $90^{\circ} 01^{\prime}$ and $90^{\circ} 15^{\prime}$ east longitudes. It is bounded by Mirzapur and Kaliakair upazilas on the north, Singair upazila on the south, Savar upazila on the east Manikganj sadar, Saturia and Nagarpur upazilas on the west. Dhamrai thana was formed in 1914 and it was turned into an upazila in 1985. Dhamrai upazila has 16 unions and 408 villages. Out of 408 villages of Dhamrai upazila 6 villages were selected randomly as the locale of the study. The selected villages were Sharif bug, Bandimara, Dephashai, Assulia, Dhamran and Fukuria.

The farmers of the selected villages using best management practices were considered to be the population of the study. An up-t-date list of farmers of these villages was prepared with the help of Sub-Assistant Agricultural Officer (SAAO) of the study area. The total number of the farmers was 1680 which constituted the population of the study. Five percent of population was considered as sample of the study (Table-1). Besides, a reserved list of 9 farmers was prepared to be interviewed in time of needed.

Table-1: Distribution of population, sample and reserve list of the study area

\begin{tabular}{|l|c|c|c|}
\hline \multicolumn{1}{|c|}{ Name of village } & Population & Sample size & Reserved list \\
\hline Sharif bug & 234 & 12 & 1 \\
\hline Bandimara & 301 & 15 & 2 \\
\hline Dephashai & 253 & 13 & 1 \\
\hline Assulia & 212 & 11 & 2 \\
\hline Dhamran & 345 & 17 & 2 \\
\hline Fukuria & 335 & 16 & $\mathbf{9}$ \\
\hline Total & $\mathbf{1 6 8 0}$ & $\mathbf{8 4}$ & \\
\hline
\end{tabular}

\subsection{Data Collection Methods}

Individual interviews were used in the survey and were conducted in a face-to- face [6] situation by the researcher. A structured interview schedule was prepared containing open and closed formed questions. The schedule was pre-tested with 10 randomly selected best management practices farmers in the study area. The pre-test was helpful in identifying faulty questions and statements in the draft schedule. Data were collected by the researcher personally. The primary data were collected from February to March, 2019.

\subsection{Variable of the Study}

Success of a research to a considerable extent depends on the successful selection of the variables. Irrational, inappropriate and inconsistent selection of variables may lead to misleading and unfruitful results. The researcher keeping all these in mind took adequate care in selecting the variables of the study. Moreover, the researchers visited the study area several times and talked to the crop growing farmers intimately. Therefore, based on knowledge about study area, extensive literature review and discussions with relevant experts and academicians, the researchers selected seventeen characteristics of the farmers which were considered as independent variables for the study. These are age, education, family size, area under crop cultivation, homestead area, annual family income, off farm income, homestead vegetable cultivation, experience in crop cultivation, time spent in farming, agricultural training, cropping pattern, distance of home to local 
market, distance of home to upazila agriculture office, contact with SAAO, ownership of mobile and use of mobile phone. On the other hand, use of best management practices by the farmers was the dependent variable. Appropriate scale was used to measure the independent variables. To measure the dependent variable, a list of 15 best management practices used by the farmers of the study area since long ago was selected. Then, they ask how many number of best management practices was practiced by the farmers then divided by total number of best management practices. Thus, the range of best management practice score of a respondent could vary from 0.20 to 0.87 where, 0.20 indicates low use of practice and 0.87 indicate the highest use of best management practices.

\section{RESULTS AND DISCUSSION}

\subsection{Selected Characteristics of the Farmers}

Table-2: The salient feature of selected characteristics of the farmers

\begin{tabular}{|c|c|c|c|c|c|c|c|}
\hline \multirow{2}{*}{$\begin{array}{l}\text { Variables } \\
\text { ( Measuring } \\
\text { Unit) }\end{array}$} & \multicolumn{2}{|c|}{ Range } & \multirow[t]{2}{*}{ Categories } & \multicolumn{2}{|c|}{ Respondents' } & \multirow[t]{2}{*}{ Mean } & \multirow[t]{2}{*}{ SD } \\
\hline & $\begin{array}{l}\text { Minimu } \\
\mathrm{m}\end{array}$ & $\underset{\mathrm{m}}{\operatorname{Maximu}}$ & & Number & Percent & & \\
\hline Age (Years) & 21 & 75 & $\begin{array}{l}\text { Young (up to 35) } \\
\text { Middle (36-50) } \\
\text { Old ((> 50) }\end{array}$ & $\begin{array}{l}25 \\
30 \\
29\end{array}$ & $\begin{array}{l}29.8 \\
35.7 \\
34.5\end{array}$ & 46.54 & 13.84 \\
\hline $\begin{array}{l}\text { Education (Years } \\
\text { of schooling) }\end{array}$ & .00 & 16.00 & $\begin{array}{l}\text { Illiterate }(0-0.5) \\
\text { Primary } 91-5) \\
\text { Secondary }(6-10) \\
\text { Above secondary }(>10)\end{array}$ & $\begin{array}{l}24 \\
11 \\
36 \\
13\end{array}$ & $\begin{array}{l}28.6 \\
13.1 \\
42.8 \\
15.4\end{array}$ & 6.54 & 4.78 \\
\hline $\begin{array}{l}\text { Family size } \\
\text { (Person) }\end{array}$ & 2 & 16 & $\begin{array}{l}\text { Small family (upto 4) } \\
\text { Medium family (5-8) } \\
\text { Large family (>8) }\end{array}$ & $\begin{array}{c}32 \\
45 \\
7 \\
\end{array}$ & $\begin{array}{c}38.1 \\
53.6 \\
8.3 \\
\end{array}$ & 5.54 & 2.47 \\
\hline $\begin{array}{l}\text { Area under crop } \\
\text { cultivation }(\mathrm{Ha})\end{array}$ & .00 & 3.10 & $\begin{array}{l}\text { Marginal farm (up to } 0.20) \\
\text { Small farm }(021-1) \\
\text { Medium farm }(1.01-3) \\
\text { Large farm }(>3)\end{array}$ & $\begin{array}{c}15 \\
56 \\
12 \\
1\end{array}$ & $\begin{array}{c}17.9 \\
66.6 \\
14.3 \\
1.2\end{array}$ & .63 & .59 \\
\hline $\begin{array}{l}\text { Homestead area } \\
\text { (Decimal) }\end{array}$ & 2 & 52 & $\begin{array}{l}\text { Small area (upto } 3) \\
\text { Medium area }(4-23) \\
\text { Large area }(>23)\end{array}$ & $\begin{array}{c}6 \\
65 \\
13\end{array}$ & $\begin{array}{c}7.1 \\
77.4 \\
15.5\end{array}$ & 13.57 & 10.19 \\
\hline $\begin{array}{l}\text { Annual income } \\
\text { from agriculture } \\
(' 000 \text { ') }\end{array}$ & 16 & 670 & $\begin{array}{l}\text { Low income (upto 223) } \\
\text { Medium income }(224-446) \\
\text { High income }(>446)\end{array}$ & $\begin{array}{c}64 \\
17 \\
3 \\
\end{array}$ & $\begin{array}{c}76.2 \\
20.2 \\
3.6\end{array}$ & 154.29 & 136.96 \\
\hline $\begin{array}{l}\text { Off farm income } \\
(' 000 ')\end{array}$ & 0 & 264 & $\begin{array}{l}\text { Low income (upto } 88) \\
\text { Medium income }(89-176) \\
\text { High income }(>176)\end{array}$ & $\begin{array}{l}55 \\
15 \\
14 \\
\end{array}$ & $\begin{array}{l}65.5 \\
17.8 \\
16.7 \\
\end{array}$ & 78.70 & 74.67 \\
\hline $\begin{array}{l}\text { Homestead } \\
\text { vegetable } \\
\text { cultivation } \\
\text { (Score) }\end{array}$ & 0 & 1 & $\begin{array}{l}\text { Yes }(1) \\
\text { No }(0)\end{array}$ & $\begin{array}{l}59 \\
25\end{array}$ & $\begin{array}{l}70.2 \\
29.8\end{array}$ & .70 & .46 \\
\hline $\begin{array}{l}\text { Experience in } \\
\text { crop cultivation } \\
\text { (Years) }\end{array}$ & 1 & 65 & $\begin{array}{l}\text { Low experience (upto } 10) \\
\text { Medium experience }(11-36) \\
\text { High experience }(>36)\end{array}$ & $\begin{array}{l}18 \\
43 \\
21 \\
\end{array}$ & $\begin{array}{c}21.4 \\
53.6 \\
25 \\
\end{array}$ & 26.18 & 16.83 \\
\hline $\begin{array}{l}\text { Time spent in } \\
\text { farming (hours) }\end{array}$ & 0 & 10 & $\begin{array}{l}\text { Low time spent (upto 3) } \\
\text { Medium time spent (4-7) } \\
\text { High time spent }(>7)\end{array}$ & $\begin{array}{l}19 \\
49 \\
16\end{array}$ & $\begin{array}{c}22.6 \\
58.4 \\
19\end{array}$ & 5.19 & 2.19 \\
\hline $\begin{array}{l}\text { Agricultural } \\
\text { training (Days) }\end{array}$ & 0 & 15 & $\begin{array}{l}\text { No training }(0) \\
\text { Low training }(1-5) \\
\text { Medium training }(6-10) \\
\text { High training }(>10)\end{array}$ & $\begin{array}{l}24 \\
26 \\
23 \\
11\end{array}$ & $\begin{array}{l}28.6 \\
30.9 \\
27.4 \\
13.1\end{array}$ & 4.44 & 4.41 \\
\hline $\begin{array}{l}\text { Cropping pattern } \\
\text { (Number) }\end{array}$ & 0 & 5 & $\begin{array}{l}\text { Low pattern (upto } 0-1) \\
\text { Medium pattern }(2-3) \\
\text { High pattern }(>3)\end{array}$ & $\begin{array}{c}12 \\
69 \\
3\end{array}$ & $\begin{array}{c}14.3 \\
82.1 \\
3.6 \\
\end{array}$ & 2.36 & .86 \\
\hline $\begin{array}{l}\text { Distance of home } \\
\text { to local market } \\
(\mathrm{Km})\end{array}$ & .25 & 6 & $\begin{array}{l}\text { Short distance (upto 2) } \\
\text { Medium distance (3-4) } \\
\text { Long distance }(>4)\end{array}$ & $\begin{array}{c}59 \\
20 \\
5\end{array}$ & $\begin{array}{c}70.2 \\
23.8 \\
6\end{array}$ & 1.93 & 1.33 \\
\hline
\end{tabular}




\begin{tabular}{|c|c|c|c|c|c|c|c|}
\hline $\begin{array}{l}\text { Distance of home } \\
\text { to upazila } \\
\text { agriculture } \\
\text { officer }(\mathrm{Km})\end{array}$ & .25 & 9 & $\begin{array}{l}\text { Short distance (upto 3) } \\
\text { Medium distance (4-6) } \\
\text { Long distance (>6) }\end{array}$ & $\begin{array}{c}67 \\
15 \\
2\end{array}$ & $\begin{array}{c}79.8 \\
17.8 \\
2.4\end{array}$ & 2.24 & 1.51 \\
\hline $\begin{array}{l}\text { Contact with } \\
\text { SAAO (Number) }\end{array}$ & 0 & 64 & $\begin{array}{l}\text { Low contact (upto 3) } \\
\text { Medium contact (4-31) } \\
\text { High contact (>31) }\end{array}$ & $\begin{array}{l}12 \\
57 \\
15\end{array}$ & $\begin{array}{l}14.3 \\
67.8 \\
17.9\end{array}$ & 17.87 & 14.99 \\
\hline $\begin{array}{l}\text { Ownership of } \\
\text { mobile phone } \\
\text { (Score) }\end{array}$ & 0 & 1 & $\begin{array}{l}\text { Yes }(1) \\
\text { No }(0)\end{array}$ & $\begin{array}{l}65 \\
19\end{array}$ & $\begin{array}{l}77.4 \\
22.6\end{array}$ & .77 & .42 \\
\hline $\begin{array}{l}\text { Use of mobile } \\
\text { phone (Score) }\end{array}$ & 0 & 1 & $\begin{array}{l}\text { Yes (1) } \\
\text { No (0) }\end{array}$ & $\begin{array}{r}52 \\
32 \\
\end{array}$ & $\begin{array}{l}61.9 \\
38.1 \\
\end{array}$ & .62 & .48 \\
\hline
\end{tabular}

Farmers aged were classified into three categories according to the [7]. The lowest and highest ages of the farmers were 21 and 75 years respectively with an average of 46.54 . The mean value indicates majority of farmers were middle aged. Most $(70.2 \%)$ of the respondents were in middle to old aged. The data revealed that the highest percentage (42.8\%) of the farmers had secondary level of education. Based on their family size, the respondents were classified into three categories following the categorization according to [8]. The majority of the farmer's small to medium family size (91.7\%). The average family size of the respondents of the study area (5.54) was higher than that of national average (4.4) of Bangladesh [8]. Based on their area under crop cultivation, the farmers were classified into three categories following the categorization according to [9]. Majority of the respondents had small to marginal farm size (84.5\%). The average farm size of the farmers of the study area ( $0.63 \mathrm{ha})$ was higher than that of national average $(0.15 \mathrm{ha})$ of Bangladesh [2]. Medium to large homestead area (92.9\%) and low to medium annual family income (96.4\%) of this study area. The majority $(76.2 \%)$ of the farmers had low annual family income and low to medium off farm income about $83.3 \%$. About three-third $(70.2 \%)$ of the farmers had homestead vegetable cultivation. Just above half (53.6\%) of the farmers had medium experience in crop cultivation. Overwhelming $(75.0 \%)$ of the farmers had low to medium time spent in farming. Low agricultural training farmers had highest 30.9 percent in this study area. Low to medium cropping pattern had highest in this study area. Data presented in the Table 3, revealed that $70.2 \%$ of the farmers belonged to short distance of home to local market and $79.8 \%$ had short distance of home to upazila agriculture office. About three-third (67.8\%) of the farmers had medium contact with SAAO. The majority (77.4\%) of the farmers had ownership of mobile phone and $61.9 \%$ of the farmers had use of mobile phone.

\subsection{Use of Best Management Practices by the Farmers}

Use of best management practices by the farmers was the dependent variable of the study. The observed best management practices scores of the farmers ranged from 0.20- 0.87. The mean scores were 0.56 with the standard deviation of 0.15 . Based on their best management scores, the farmers were classified into three categories namely low practice, medium practice and high practice as shown in Table 3.

Table-3: Distribution of farmers according to their Best management practices

\begin{tabular}{|l|c|c|c|c|}
\hline \multirow{2}{*}{ Categories (Scores) } & \multicolumn{2}{|c|}{ Farmers } & \multirow{2}{*}{ Mean } & \multirow{2}{*}{ SD } \\
\cline { 2 - 3 } & Number & Percent & & \\
\hline Low (up to 0.41) & 19 & 22.6 & \multirow{2}{*}{0.56} & 0.15 \\
\hline Medium (0.42-.71) & 51 & 60.7 & \\
\hline High $(>0.71)$ & 14 & 16.7 & \\
\hline Total & 84 & 100 & \\
\hline
\end{tabular}

The data presented in the Table 3 revealed that the majority (60.7\%) of the respondents had medium best management practices compared to $(22.6 \%)$ and $(16.7 \%)$ having low best management practices and high best management practices. Table 3 also reveals that almost ( $83.3 \%$ ) of the farmers had low to medium best management practices. This could be due to the fact that most of the best management practices farmers were middle to old in aged, had low education which created low use of best management practices by the farmers.

\subsection{Contribution of the Selected Characteristics of the Farmers to their Use of Best Management Practices}

In order to find out significant factors influencing use of best management practices by the farmers, multiple regression analysis was used which is shown in the Table-4. 
Table-4: Multiple regression coefficients of the contributing variables related to their best management practices

\begin{tabular}{|l|c|c|c|c|c|}
\hline \multirow{2}{*}{ Variables } & \multicolumn{2}{c|}{$\begin{array}{c}\text { Unstandardized } \\
\text { coefficients }\end{array}$} & $\begin{array}{c}\text { Standardized } \\
\text { Coefficients }\end{array}$ & \multirow{2}{*}{ Sig } \\
\cline { 2 - 5 } & $\mathbf{B}$ & Std. error & Beta & & \\
\hline Education $\left(\mathrm{x}_{2}\right)$ & .010 & .003 & .318 & 3.873 & .000 \\
\hline Use of mobile phone $\left(\mathrm{x}_{17}\right)$ & .097 & .026 & .309 & 3.707 & .000 \\
\hline Time spent in farming $\left(\mathrm{x}_{10}\right)$ & .016 & .004 & .224 & 3.542 & .001 \\
\hline Contact with SAAO $\left(\mathrm{x}_{15}\right)$ & .002 & .001 & .199 & 2.924 & .005 \\
\hline Ownership of mobile phone $\left(\mathrm{x}_{16}\right)$ & .057 & .026 & .156 & 2.179 & .032 \\
\hline
\end{tabular}

Table-5: Summary of Best management practices

\begin{tabular}{|c|c|c|c|c|}
\hline Model & R & R Square & Adjusted R Square & Std. Error of the Estimate \\
\hline 1 & $.703^{\mathrm{a}}$ & .495 & .488 & .109924 \\
2 & $.774^{\mathrm{b}}$ & .598 & .589 & .098579 \\
3 & $.816^{\mathrm{c}}$ & .666 & .654 & .090406 \\
4 & $.835^{\mathrm{d}}$ & .697 & .681 & .086763 \\
5 & $.845^{\mathrm{e}}$ & .714 & .696 & .084775 \\
\hline
\end{tabular}

a. Predictors: (Constant), education

b. Predictors: (Constant), education, use of mobile phone

c. Predictors: (Constant), education, use of mobile phone, time spent

d. Predictors: (Constant), education, use of mobile phone, time spent, contact with SAAO

e. Predictors: (Constant), education, use of mobile phone, time spent, contact with SAAO, ownership of mobile phone

The contribution of education was positive and significant which indicates that the higher the education the higher the use of best management practices. This was the highest important factors influencing use of best management practices. In fact, education can play an important role in use of best management practices by the farmers. During the education period, the farmers mentioned that they can gain more knowledge and skills in the use of best management practices.

The farmers also influenced by the use of mobile phone in using best management practices. Mobile phone can play an important role in using best management practice. Use of mobile phone can help the farmers to know different information about use of best management practices through browsing internet, call centre etc.

Time spent in farming had another factor that influences farmers' use of best management practices. If farmers had spent more time in farming use of best management practices ultimately increases.

From analysis, it was showed that contact with SAAO of the farmers had the positive contribution to their use of best management practices. This implies that with the increase of contact with SAAO of the farmers their use of best management practices will be increased. Contact with SAAO plays an important role in use of best management practices. Continuous contact with SAAO help farmers to become aware about use of best management practices, learn about best management practices technologies, understand advantages of best management practices which increase the use of best management practices.

The farmers were also influenced by their ownership of mobile phone. This implies that with the increase of ownership of mobile phone by the farmers it would be increased their extent of use of best management practices. From descriptive statistics, it was found that 61.9 percent farmers belong to ownership of mobile phone. Thus, ownership of mobile phone plays an important role in use of best management practices.

\section{CONCLUSIONS AND RECOMMENDATION}

The study was conducted in a region where farmer uses best management practices. To understand the scenario regarding extent of best management practices of the farmers of that region, three objectives were set which one is to determine the extent of use of best management practices by the farmers and to find out the influencing factor of use of best management practices is another. Five factors namely education, use of mobile phone, time spent in farming, contact with SAAO and ownership of mobile phone were significantly influenced the farmers in using best management practices. Therefore, it can be recommended that initiative should be taken by the DAE with the help of other relevant organizations to increase these facilities (significant factors) to improve the scenario regarding use of best management practices. 


\section{REFERENCES}

[1]. BBS. 2019. Yearbook of Agricultural Statistics of Bangladesh, Bangladesh Bureau of Statistics, Statistical Division, Ministry of Planning, Government of the People's Republic of Bangladesh, Dhaka.

[2]. BBS. 2014. Yearbook of Agricultural Statistics of Bangladesh, Bangladesh Bureau of Statistics, Statistical Division, Ministry of Planning, Government of the People's Republic of Bangladesh, Dhaka.

[3]. Asiabaka, C. 2002. Promoting Sustainable Extension Approaches: Farmer Field School (FFS) and its role in sustainable agricultural development in African. Int. J. Agric. Rural Dev., 3: 46-53.

[4]. Jamal, E. 2009. Assessment of farmer field school in integrated crop management of rice commodity: Case study in Blitar and Kediri Regency, West Java. J. Policy Anal., 7(4): 377-349.

[5]. Suhendrata, T. 2008. The role of agricultural technology innovation in increasing rice productivity in support of food security. In Proceedings of the National Seminar on Agricultural Engineering. Yogyakarta.

[6]. Bryman, A. 2001. Social Research Methods. Oxford: Oxford University Press.

[7]. MoYS. 2012. The Population Category in Bangladesh. Ministry of Youth and Sports, Government of the People's Republic of Bangladesh.

[8]. BBS. 2018. Yearbook of Agricultural Statistics of Bangladesh, Bangladesh Bureau of Statistics, Statistical Division, Ministry of Planning, Government of the People's Republic of Bangladesh, Dhaka.

[9]. DAE. 1999. Agriculture Extension Manual. Department of Agricultural Extension, Ministry of Agriculture, Government of the People's Republic of Bangladesh. 